$\begin{gathered}\text { Revista do Departamento de Geografia } \\ \text { Universidade de São Paulo } \\ \text { www.revistas.usp.br/rdg }\end{gathered}$
V.32 (2016)

\title{
Suscetibilidade à Ocorrência de Movimentos de Massa no Maciço de Baturité- Ceará, Brasil
}

\author{
Susceptibility to the Occurrence of Mass Movements \\ in Baturité Massif - Ceará, Brazil
}

\author{
Frederico de Holanda Bastos \\ Universidade Estadual do Ceará \\ fred.holanda@uece.br \\ Jean-Pierre Peulvast \\ Paris - Sorbonne IV \\ jean-pierre.peulvast@wanadoo.fr
}

Resumo: Os estudos de movimentos de massa são muito importantes na compreensão da evolução geomorfológica e na identificação de áreas de risco morfodinâmico. O maciço de Baturité se apresenta como a maior serra úmida do Ceará. Sua altitude média gira em torno de $800 \mathrm{~m}$, podendo atingir $1.000 \mathrm{~m}$. Do ponto de vista geomorfológico, constata-se uma grande variedade de feições tais como relevos dissecados nas vertentes, colinas intercaladas com planícies alveolares no platô e superfícies de erosão e de deposição nos setores circunvizinhos mais baixos. A distribuição e características dos movimentos de massa variam de acordo com as propriedades de cada área. Foram identificados movimentos de massa somente nas áreas com declives mais significativos, que se encontram basicamente nas vertentes e no platô. De maneira geral, constatou-se a ocorrência de deslizamentos rotacionais e translacionais associados com fluxos de lama e quedas de blocos. Tendo em vista a necessidade de elaborar mapeamentos voltados para a identificação de áreas de suscetibilidade morfodinâmica, foram estabelecidos critérios metodológicos envolvendo os agentes desencadeadores através de técnicas de álgebra de mapas. Foram identificadas áreas com alta suscetibilidade, nas vertentes ocidental, meridional e parte da oriental, áreas com suscetibilidade média nos demais setores elevados do maciço, e baixa suscetibilidade nas áreas circunvizinhas.

Palavras chave: Movimentos da Massa. Maciços Úmidos do Nordeste. Planejamento Ambiental.

\begin{abstract}
Studies of mass movements are very important for understanding the geomorphologic evolution and identifying morphodynamic risk areas. The Baturite massif presents itself as the most significant wet hill of Ceará. Its average altitude is around $800 \mathrm{~m}$, and may have ridges above 1,000 m. From the geomorphologic point of view, there is a wide variety of features such as reliefs dissected on the hillsides, interspersed rolling hills with the deposition plains and surfaces of erosion and deposition in the lower surrounding areas. The distribution and characteristics of mass movements vary according to the properties of each area. Mass movements have been identified only in the areas with the most significant slopes, which are essentially found in uphills and in the plateau. In general, it was observed the occurrence of rotational and translational landslides associated with mud flows and falls. Considering the need to develop mappings aimed at identifying areas of morphodynamic susceptibility, methodological criteria involving the triggering agents using techniques of maps algebra were established. As a result, we identified areas with high susceptibility, in the western and southern hillsides and part of the eastern areas, with average susceptibility in other sectors of the uphill and low susceptibility in the surrounding areas.
\end{abstract}

Keywords: Mass Movements. Northeast Wet Hills. Environmental Planning. 


\section{INTRODUÇÃO}

Os movimentos de massa em encostas se caracterizam pela dissipação significativa de energia e consequente deslocamento de materiais terrestres, tais como rochas, solo e mantos de intemperismo, sob a ação da gravidade (PICANÇO, 2010). Esses fenômenos apresentam uma grande importância para a geomorfologia, contribuindo na compreensão da evolução das vertentes e para os estudos relacionados com planejamento ambiental, tendo em vista as informações fornecidas inerentes à identificação de possíveis áreas de risco.

As características geomorfológicas do Brasil, associadas à presença de significativos maciços montanhosos, implicam na ocorrência de importantes eventos relacionados com movimentos de massa e isso tem se configurado como um grave problema socioeconômico.

Nos últimos anos tem-se evidenciado um número cada vez maior de desastres naturais relacionados com movimentos de massa, sobretudo nos relevos serranos das regiões Sul e Sudeste do Brasil. Tragédias como as de 2011 nas serras fluminenses, 2010 em Angra dos Reis e 2008 e 2009 no estado de Santa Catarina, ganharam espaço importante nos meios de comunicação nacionais e internacionais, tendo em vista a grande quantidade de perda de vidas humanas.

Apesar do predomínio de significativos movimentos de massa nos maciços montanhosos das regiões Sul e Sudeste, em todas as regiões brasileiras pode-se deparar com ambientes instáveis sujeitos à possibilidade de desencadeamento de eventos dessa natureza.

No Nordeste brasileiro encontra-se o domínio morfoclimático semiárido das caatingas brasileiras (AB'SABER, 1974), que apresenta um mosaico paisagístico bastante heterogêneo, com uma série de ambientes serranos de exceção onde as caatingas dão lugar a outros representantes fitogeográficos, como é o caso dos enclaves úmidos recobertos por florestas.

Souza e Oliveira (2006) destacam que os enclaves úmidos e subúmidos se distribuem de modo disperso pelos sertões semiáridos, configurando superfícies topograficamente elevadas de relevos serranos com dimensões variadas e que são submetidos às influências de mesoclimas.

O estado do Ceará apresenta cerca de $90 \%$ do seu território sob condições climáticas semiáridas, porém, vários brejos de altitude contrastam com os sertões secos recobertos pelas caatingas. As serras úmidas do Ceará se caracterizam como áreas de grande importância socioeconômica, em função das melhores condições edafo-climáticas, que proporcionam uma elevada produtividade agrícola e um denso contingente populacional, quando comparadas às demais áreas sertanejas.

O maciço de Baturité, situado a uma distância de aproximadamente 50 km de Fortaleza, abriga em seus pontos mais elevados uma complexa cobertura vegetal que serve de refúgio para a fauna e se projeta como condição indispensável para o abastecimento hídrico de diferentes bacias hidrográficas, cuja importância é fundamental tanto para a área do maciço como para a região metropolitana de Fortaleza (SUPERINTENDÊNCIA ESTADUAL DO MEIO AMBIENTE SEMACE, 1992). Esse relevo se destaca como o maciço úmido de maior dimensão espacial do estado.

As características ambientais diferenciadas do maciço de Baturité justificaram processos de ocupação variados ao longo de sua história, com distintos ciclos econômicos, desde atividades predominantemente agrícolas como a bananicultura, culturas de sequeiro e cafeicultura, até o desenvolvimento de atividades turísticas, nas últimas décadas.

Tendo em vista as exuberantes potencialidades naturais do maciço de Baturité associadas a uma crescente pressão exercida pela ação antrópica, foi instituída uma unidade de conservação de uso sustentável conforme decreto $\mathrm{N}^{\circ} 20.956$ de 18 de setembro de 1990, que estabeleceu como Área de Proteção Ambiental (APA) o setor delimitado a partir da cota de $600 \mathrm{~m}$.

Alguns setores do maciço de Baturité possuem os mais elevados índices pluviométricos do Ceará, justificando uma dinâmica natural diferenciada, com espessos mantos de intemperismo, associados a solos profundos, além da presença de uma cobertura vegetal perenifólia, representada 
pela mata plúvio-nebular. O relevo se apresenta fortemente dissecado em função de fatores estruturais e devido à elevada capacidade de entalhe da rede de drenagem.

Os aspectos ambientais dessas áreas serranas justificam a ocorrência de movimentos de massa significativos, sobretudo em função de fatores geológicos, pedológicos, pluviométricos e topográficos associados a formas predatórias de uso e ocupação do solo.

Os movimentos de massa que ocorrem no maciço de Baturité podem apresentar elevada capacidade energética em função das acentuadas declividades de algumas encostas, o que intensifica a ação do transporte de material rochoso ou intemperizado, podendo justificar a ocorrência de eventos catastróficos como significativos deslizamentos sobre estradas ou áreas residenciais.

Os estudos associados aos movimentos de massa no maciço de Baturité ainda não tiveram a devida atenção por parte do poder público estadual e isso gera uma grande preocupação tendo em vista o risco de eventos morfodinâmicos catastróficos. Nessa perspectiva, cabe destacar os movimentos de massa que ocorreram na serra de Maranguape, em 1974 (GUIDICINI; NIEBLE, 1984), que foram responsáveis pela morte de 14 pessoas, além dos danos em dezenas de propriedades. É importante ressaltar que a serra de Maranguape se trata de um ambiente serrano com características naturais similares ao maciço de Baturité.

Dependendo das condições ambientais, na área de estudo podem ocorrer diferentes tipos de movimentos de massa. Desta forma, é fundamental que se compreenda a distribuição espacial dos movimentos de massa, os fatores responsáveis pelo seu desencadeamento, suas características, tais como o material envolvido, capacidade energética e velocidade para que se possa compreender a evolução morfogênica das paisagens e a dimensão dos possíveis danos socioeconômicos relacionados.

Nessa perspectiva, o presente trabalho busca apresentar uma análise acerca dos movimentos de massa no maciço de Baturité, destacando sua classificação, características e ocorrência, de maneira a contribuir na elaboração de uma metodologia para o mapeamento das áreas de suscetibilidade à ocorrência de novos eventos. Dessa forma, espera-se contribuir para um melhor entendimento acerca da evolução das vertentes nesses ambientes serranos, além de ajudar na elaboração de políticas públicas voltadas para o planejamento e gestão ambiental em escala regional.

\section{CARACTERIZAÇÃO GERAL DO QUADRO NATURAL DO MACIÇO DE BATURITÉ}

O maciço de Baturité trata-se de um relevo composto, quase que em sua totalidade, por rochas do embasamento cristalino do Pré-Cambriano, compondo parte do setor setentrional da Província Borborema (ARTHAUD et al., 2008). A zona estudada pertence igualmente à margem equatorial brasileira cretácea, que trata-se de uma margem passiva transformante formada depois da abertura do Atlântico Equatorial no Aptiano-Albiano (MATOS, 2000), e ao ombro noroeste do rift Potiguar, de idade cretácea, que representa a terminação setentrional da grande zona de rift abortada CaririPotiguar (MATOS, 1992; BÉTARD; PEULVAST, 2011).

$\mathrm{Na}$ área do maciço de Baturité, as rochas supra-crustais do Complexo Ceará (reagrupando as unidades Canindé e Independência: CPRM, 2003) são dominadas por gnaisses com fácies de anfibolito de idade paleoproterozóica, mais ou menos remobilizados e migmatizados, e intercalados com diferentes afloramentos menores de quartzitos, micaxistos, mármores e intrusões leucograníticas. Todas essas estruturas foram afetadas por um importante tectonismo de cavalgamento do tipo himalaiano durante a orogênese Brasiliana (Proterozóico Superior/Cambriano), o último dos grandes episódios de aglutinação continental que caracterizam a estruturação continental do embasamento nordestino (MONIÉ et al., 1997; ALMEIDA et al., 2000). Na parte oriental da área de estudo, o embasamento é parcialmente recoberto pelos sedimentos detríticos cenozóicos, pouco espessos, que caracterizam a Formação Barreiras, a qual se estende sobre o conjunto da zona costeira do Estado do Ceará (CPRM, 2003). 
Sob o ponto de vista geomorfológico ele se inclui no domínio dos escudos e maciços antigos compostos por rochas do Pré-Cambriano (SOUZA, 1988). Os níveis altimétricos alcançam, em média, cotas entre $600-800 \mathrm{~m}$, podendo, em algumas cristas, alcançarem cotas acima de $900 \mathrm{~m}$ (Figura 1), como é o caso do Pico Alto (Guaramiranga), com $1.114 \mathrm{~m}$.

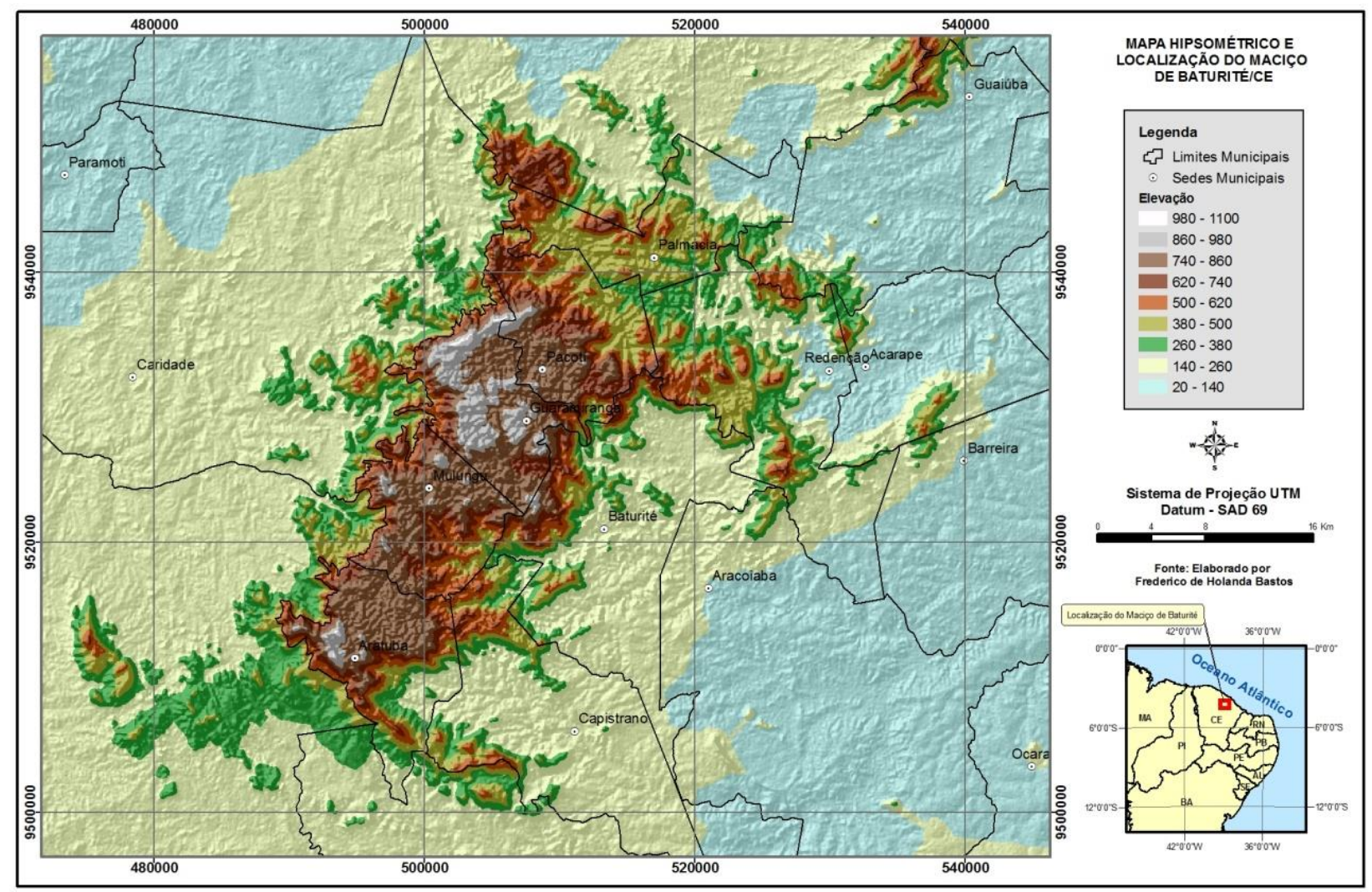

Figura 1: Hipsometria e localização do maciço de Baturité/CE.

Para Claudino Sales e Peulvast (2007), os maciços cearenses de Baturité, Uruburetama, Aratanha, Maranguape e Conceição se apresentam dissociados em vários volumes de relevos isolados e, tendo em vista a ausência de falhas capazes de sugerir uma divisão tectônica, seus atuais isolamentos espaciais se devem à erosão consecutiva e ao soerguimento do conjunto, a partir do Neocomiano. Para os referidos autores, o maciço de Baturité se apresenta como um vestígio do ombro ocidental do rifte Potiguar e é provável que ele tenha sofrido novos soerguimentos em resposta ao soerguimento flexural da margem continental, após o Neocomiano, (ZEMBRUSCKI et al., 1975; BELTRAMI et al, 1994; CLAUDINO SALES; PEULVAST, 2007; PEULVAST; CLAUDINO SALES, 2004; BÉTARD; PEULVAST, 2011; PEULVAST; BÉTARD, 2013).

Nas superfícies elevadas do maciço encontram-se setores fortemente dissecados com vales em "V", com a presença de pães de açúcar, sobretudo na parte setentrional. Associados com rochas quartzíticas encontram-se cristas aguçadas ao longo das vertentes ocidental e meridional, enquanto que no platô predominam colinas convexas intercaladas com planícies alveolares.

Nas áreas mais baixas de entorno (piemont) encontram-se superfícies de erosão (sertões) e de acumulação (tabuleiros). Em alguns trechos evidenciam-se inselbergs de diferentes dimensões se destacando topograficamente ao longo das superfícies sertanejas circunvizinhas.

A ação combinada da altitude e da exposição do relevo face aos deslocamentos das massas de ar úmidas oriundas do oceano faz com que alguns setores da área de estudo possuam os mais elevados índices pluviométricos do Ceará, com médias anuais acima de 1.500mm (SEMACE, 1992). 
De acordo com Zanella e Sales (2011), o maciço de Baturité constitui-se numa região serrana com pluviosidade que o enquadra como área de clima úmido na vertente a barlavento, subúmido à sotavento e semiárido nas áreas circunvizinhas.

Dados apresentados por Zanella e Sales (op. cit.) demonstram médias térmicas de $24,2^{\circ} \mathrm{C}$ em Palmácia $(420 \mathrm{~m}), 21,8^{\circ} \mathrm{C}$ em Pacoti $(735 \mathrm{~m})$ e $20,8^{\circ} \mathrm{C}$ em Guaramiranga $(860 \mathrm{~m})$, o que demonstra a influência das altitudes na diminuição da temperatura, já que esses municípios se encontram no platô do maciço. Apesar de se observar diferenças entre si em municípios elevados do maciço de Baturité, essa diferença é muito maior quando comparada aos municípios mais baixos localizados nas áreas semiáridas circunvizinhos, com médias superiores a $26^{\circ} \mathrm{C}$.

Nas vertentes ocidental e meridional do maciço o relevo apresenta uma forte relação com os dobramentos de quartzito da Unidade Independência em função de sua grande resistência. Essas duas vertentes, situadas nos setores de sotavento, apresentam clima mais seco que justificam a presença de solos rasos (neossolos litólicos) recobertos por uma unidade fitogeográfica denominada floresta subcaducifólia tropical (mata seca) (BASTOS, 2012).

Nos setores mais úmidos do maciço (vertente oriental e platô), as condições climáticas propiciam a ocorrência de grandes mantos de alteração, com solos muito profundos (argissolos vermelho amarelos) recobertos por mata úmida perenifólia.

De acordo com Ministério do Meio Ambiente - MMA (1994), foram constatadas três grandes unidades de cobertura vegetal no maciço de Baturité: a vegetação da caatinga (caducifólia), a mata seca (subcaducifólia) e a mata úmida (perenifólia). Já na classificação de Fernandes et al., (2011), constata-se a presença da Floresta Ombrófila Aberta, da Floresta Estacional Semidecidual e da Caatinga.

Nas áreas mais baixas das vertentes do maciço, ou seja, na medida em que se aproxima das depressões sertanejas, pode-se constatar a presença de alguns espécimes da caatinga recobrindo luvissolos, planossolos e neossolos litólicos, onde as condições de semiaridez são cada vez mais evidentes. Em contato com a mata seca os espécimes de caatinga apresentam porte arbóreo (MMA, 1994).

A partir da cota de 600 - 800m de altitude predomina uma vegetação florestal higrófila, perenifólia ou subperenifólia, incluída no tipo pluvial de altitude. Nas partes mais altas, entre 800 $1000 \mathrm{~m}$, devido ao favorecimento durante a maior parte do ano pela condensação do vapor d'água encontram-se nuvens baixas ou nevoeiros que precipitam frequentemente em chuvas finas (FERNANDES, 1998). De maneira geral essa mata possui um estrato arbóreo, chegando a atingir até 20m, podendo-se presenciar também espécies arbustivas, ambas associadas a uma grande abundância de liquens, epífitas e lianas.

\section{CARACTERIZAÇÃO DOS MOVIMENTOS DE MASSA NO MACIÇO DE BATURITÉ}

Ab'Sáber (1969) propôs uma sistematização dos conhecimentos para pesquisas geomorfológicas destacando três dimensões de abordagem integradas que são: a compartimentação da topografia regional, a estrutura superficial das paisagens e a fisiologia das paisagens.

A análise da fisiologia das paisagens se caracteriza como uma etapa imprescindível para que se possa identificar os limites da estabilidade na dinâmica natural. No estudo da fisiologia das paisagens, enfatiza-se a análise dos processos morfodinâmicos atuais considerando-se a ação conjunta dos fatores geoecológicos (clima, vegetação, drenagem, solos, etc.) e dos agentes antropogênicos (AB'SÁBER, op. cit.).

O estudo dos processos morfodinâmicos trata-se de uma área do conhecimento de fundamental importância na ciência geomorfológica, sobretudo numa perspectiva de se compreender a evolução e o funcionamento de vertentes, talvegues, etc., além de poder contribuir para o planejamento ambiental através da identificação de áreas de riscos geomorfológicos. 
Dentre as áreas de análise relacionadas aos processos morfodinâmicos, destacam-se os estudos de movimentos gravitacionais de massa em encostas tendo em vista a sua importância para a evolução dos relevos e sua relação com eventos catastróficos.

Alguns movimentos gravitacionais de massa podem causar perdas de vidas humanas, danos civis ou interrupção geral das atividades socioeconômicas. Historicamente, lamentáveis acontecimentos com dezenas de milhares de vidas humanas perdidas têm ocorrido nos mais diversos continentes terrestres. O que torna os movimentos gravitacionais tão terríveis é o fato deles, quase sempre, ocorrerem com pouco ou nenhum aviso, cessando em espaço de tempo muito curto e deixando um legado de destruição.

As zonas tropicais úmidas são consideradas como áreas onde as vertentes estão intensamente sujeitas aos movimentos de massa, tendo em vista a abundância das chuvas e a presença de espessos mantos de intemperismo (BIGARELLA et al., 2003).

O desencadeamento de movimentos de massa em encostas pode derivar de vários fatores, tais como o papel da estrutura geológica, do regolito e solos, da geomorfologia e declividade, da pluviosidade, da cobertura vegetal e da ação antrópica.

A classificação dos movimentos de massa apresenta uma grande dificuldade, sobretudo na quantificação das variáveis envolvidas (material, conteúdo de água, velocidade e mecanismos). As terminologias encontradas na literatura não apresentam uniformidade e, geralmente, são pouco rigorosas. Existem inúmeras classificações acerca dos movimentos de massa, dentre as quais pode-se destacar a proposta feita por Sharpe em 1938 como a primeira a apresentar um caráter amplo e abrangente (BIGARELLA et al., 2003; FERNANDES e AMARAL, 2000).

Tendo em vista a necessidade de se adotar uma metodologia adequada e atualizada para classificar os movimentos de massa na área do maciço de Baturité, o presente trabalho enfatiza os trabalhos de Varnes (1978), Dikau et al. (1996) e Dikau (2004), Os trabalhos citados utilizam terminologias adotadas pela Sociedade Geotécnica Internacional, de acordo com o grupo de trabalho responsável pelos inventários acerca de movimentos de massa na Terra (Working Party on World Landslide Inventory - WP/WLI), vinculado à Organização das Nações Unidas para a Educação, a Ciência e a Cultura (UNESCO).

De maneira geral, Dikau (2004) divide os movimentos de massa em quedas (falls), tombamentos (topple), deslizamentos (slides) rotacionais e translacionais, espalhamentos laterais (lateral spreading), fluxos ou corridas (flow) e movimentos complexos (complex).

Conforme afirmado anteriormente, o maciço de Baturité apresenta uma grande diversidade paisagística ao longo de sua área o que justifica uma série de tipos diferentes de movimentos gravitacionais de massa. Tendo em vista essa complexidade, durante a elaboração do presente trabalho, foram feitos diversos levantamentos de campo ao longo da área do maciço com o intuito de mapear, com o auxílio de GPS (Sistema de Posicionamento Global), todas as áreas de ocorrência de movimentos de massa atuais e antigas cicatrizes.

De modo geral, pode-se afirmar que nos setores mais úmidos (vertente oriental e platô) ocorrem deslizamentos translacionais rasos, deslizamentos rotacionais e alguns casos de fluxos de lama. Nesses casos, vertentes com profundos mantos de intemperismo são instabilizadas pela ação antrópica, principalmente em decorrência de construção de rodovias e utilização agrícola, onde a mata úmida acaba sendo descaracterizada e a geometria das encostas alterada. A maior parte das cicatrizes de deslizamentos identificada encontra-se nas margens de rodovias, indicando o perigo associado a essas obras de infraestrutura (BASTOS, 2012).

Os argissolos que recobrem nas áreas úmidas da serra de Baturité se caracterizam pela presença de um horizonte B textural muito profundo. Em períodos de chuvas excepcionais, pode haver um significativo aumento da umidade nesse tipo de solo justificando o aparecimento de superfícies de ruptura, que podem ocorrer entre horizontes de texturas diferentes ou entre o regolito e o subtrato rochoso, que acabam configurando os planos de ruptura. Quando as superfícies de ruptura 
são planas, ocorrem os deslizamentos translacionais, que, geralmente estão associados a mantos de intemperismo pouco evoluídos. Contudo, quando essas superfícies de ruptura apresentam um aspecto curvado, acontecem os deslizamentos rotacionais. Nas áreas mais úmidas os movimentos gravitacionais podem ser bastante rápidos em decorrência dos significativos declives e do elevado volume de material envolvido (BASTOS, op cit).

Ainda se tratando das áreas mais úmidas do maciço, é possível se identificar antigas corridas de detritos, algumas apresentando seixos associados com mantos de intemperismo e outras indicando cicatrizes de quedas de grandes blocos, que indicam uma elevada capacidade energética de transporte.

Nas vertentes mais secas (setentrional, ocidental e meridional) a pequena alteração no manto superficial das rochas limita a ocorrência fluxos de lama. Nesse caso, predominam quedas individuais de bloco, deslizamentos planares rasos e alguns casos de fluxos de terra (BASTOS, op cit).

Nas cornijas quartzíticas são muito comuns quedas de blocos que se desprendem e passam a depender dos efeitos da força da gravidade. Esses setores tratam-se de áreas de forte risco morfodinâmico, sobretudo quando localizam-se próximos de áreas residenciais ou de estradas.

A ocorrência dessas quedas de blocos está relacionada com rochas fraturadas que proporcionam a acentuação da instabilidade. Nesses casos, é comum o desprendimento de blocos através da ação intempérica sobre os planos de descontinuidade das rochas.

A ação antrópica tem dado uma forte contribuição na instabilidade das vertentes. Uma das atividades mais problemáticas é a construção e manutenção de rodovias que altera a geometria das encostas, transformando encostas naturalmente instáveis em áreas de risco. Isso tem que ser analisado sob uma ótica de segurança pública face aos iminentes riscos de acidentes rodoviários.

Dentre a forte influência exercida pela ação antrópica no sentido de instabilizar vertentes, destaca-se o papel da agricultura de sequeiro, sobretudo para o plantio de milho e feijão. Essas culturas são adotadas em vertentes fortemente íngremes $\left(>35^{\circ}\right)$ a partir da utilização de técnicas predatórias e rudimentares como a prática da brocagem e das queimas.

Os processos de deslizamento das vertentes secas se apresentam com forte energia face à declividade, porém como existe uma pequena alteração no manto superficial das rochas, esses processos não possuem grande magnitude de transporte de material, até porque o regolito é pouco significativo do ponto de vista quantitativo, se comparado a outros setores mais úmidos do maciço (BASTOS, 2012).

A serra de Baturité possui vertentes fortemente instabilizadas onde já desencadearam-se significativos eventos morfodinâmicos, em áreas agrícolas e próximo de rodovias. Felizmente, não se tem notícias de fatalidades relacionadas a tais eventos morfodinâmicos, porém, nos últimos anos tem crescido, de forma bastante rápida, o mercado imobiliário para a construção de segundas residências, o que gera uma grande preocupação com a sua localização e seu risco associado.

Tendo em vista a complexidade inerente à distribuição espacial dos movimentos de massa no maciço de Baturité, a Figura 2 apresenta uma perspectiva geral de tais eventos de acordo com seus locais de ocorrência.

Face ao exposto, é fundamental que sejam elaboradas estratégias de utilização racional da terra de maneira que as instabilidades morfodinâmicas sejam observadas e respeitadas. Nessa perspectiva, é necessária a elaboração de mapeamentos em diferentes escalas no intuito de contribuir na implementação políticas públicas voltadas para ordenamento territorial. 


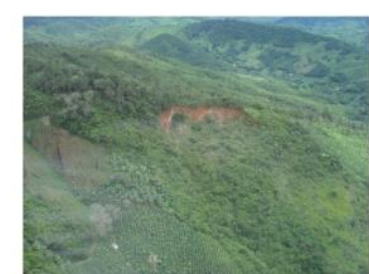

Deslizamento Rotacional

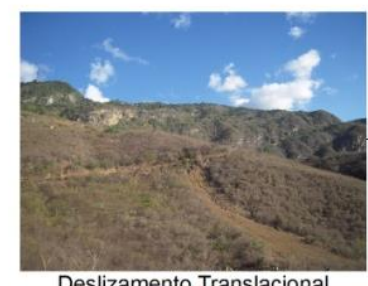

Deslizamento Translacional

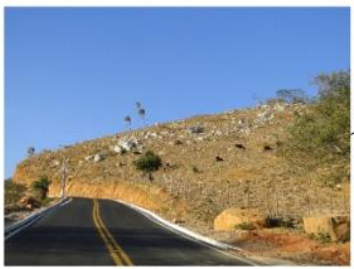

Depósito de Fluxos de Detrito

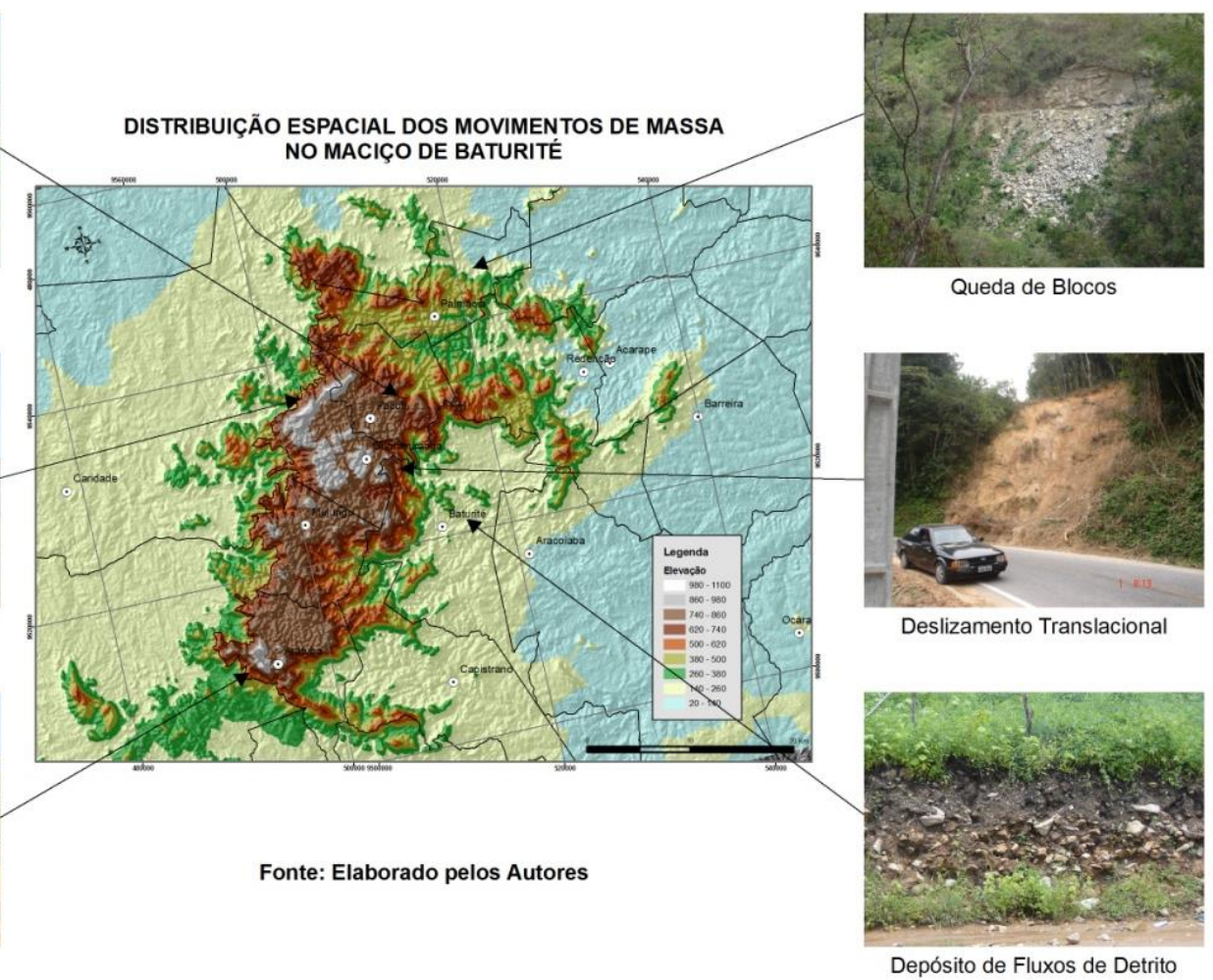

Figura 2: Distribuição espacial dos movimentos de massa no maciço de Baturité/CE.

\section{CONSIDERAÇÕES SOBRE RISCO, PERIGO E VULNERABILIDADE E SEUS MAPEAMENTOS}

Tendo em vista que a presente abordagem está focada em eventos morfodinâmicos de energia considerável, capazes de causar danos socioeconômicos, é fundamental que sejam apresentados conceitos básicos de risco e perigo.

De acordo com a UN-ISDR (2009), risco pode ser definido como a combinação da probabilidade de um determinado evento e suas consequências negativas. O risco pode ser encarado como uma categoria de análise associada às noções de incerteza, exposição ao perigo, perdas e prejuízos humanos e socioeconômicos em função de processos de ordem natural ou de origem antropogênica (CASTRO et al., 2005).

De acordo com Cerri e Amaral (1998), o risco geológico é definido como uma situação de perigo, perda ou dano ao homem e às suas propriedades, em razão da possibilidade de ocorrência de processo geológico, induzido ou não.

Para Tominaga et al., (2012), dois elementos são fundamentais na formulação do risco: o perigo e a vulnerabilidade. Dessa forma, deve-se analisar o perigo de ocorrer um evento potencialmente danoso e a vulnerabilidade, que é o grau de susceptibilidade do elemento exposto ao perigo. Assim, podem existir áreas perigosas com maior ou menor grau de vulnerabilidade.

Cerri e Amaral (1998) fazem uma distinção entre quatro definições: acidente, evento, risco e susceptibilidade. Assim, o acidente é definido como o fato já ocorrido onde tiveram danos socioeconômicos, enquanto que o evento é um fato ocorrido em que não foram registrados danos associados a ele, o risco é a possibilidade de ocorrência de um acidente e a susceptibilidade é a possibilidade de ocorrência de um evento.

Castro et al., (2005) afirmam que o risco natural está objetivamente relacionado com processos e eventos de origem natural ou induzido pela ação do homem. A natureza desses eventos é bastante diversa nas escalas espacial e temporal e, por isso, pode-se apresentar através de diferentes 
intensidades de perdas, em função da magnitude, da abrangência espacial e do tempo de duração dos eventos.

Conclui-se que o risco existe quando há um perigo com potencial de causar danos socioeconômicos. Dessa forma, é fundamental a espacialização dos perigos e riscos através de representações cartográficas, sobretudo nos projetos voltados para planejamento ambiental.

Com relação aos mapeamentos de eventos relacionados com movimentos de massa, destacamse duas abordagens distintas: os mapeamentos de perigo e os de risco. Alguns autores consideram que o mapa de perigo corresponde ao mesmo mapa de susceptibilidade.

O mapa de suscetibilidade corresponde à probabilidade espacial e temporal de ocorrer um processo com potencial de causar danos. Os métodos de avaliação da suscetibilidade são variados, pois dependem das características de cada área. Com relação ao mapa de suscetibilidade à ocorrência de movimentos de massa levam-se em consideração fatores como a susceptibilidade natural do terreno e as formas de uso e ocupação do solo que são indicativos do perigo potencial (TOMINAGA et al., 2012).

Segundo Tominaga et al., (op.cit.), na elaboração dos mapas de suscetibilidade utilizam-se duas abordagens principais: a qualitativa e a quantitativa. $\mathrm{Na}$ abordagem qualitativa, adota-se um julgamento de dados obtidos em campo ou com a utilização de sistemas de informação geográfica onde se atribuem índices aos fatores que afetam a instabilidade das encostas. Já na quantitativa, os métodos baseiam-se em análises estatísticas, por meio de comparação da distribuição espacial dos fenômenos com os parâmetros considerados buscando-se contornar a subjetividade das abordagens qualitativas.

Com a facilidade no acesso às técnicas de geoprocessamento, as metodologias de mapeamentos de risco e suscetibilidade tiveram um grande desenvolvimento nas últimas décadas, contribuindo, sobremaneira para implementação de políticas públicas voltadas para essa temática.

Os principais métodos adotados para elaboração de mapas de suscetibilidade são os empíricos, os probabilísticos e determinísticos (FERNANDES et al., 2001; TOMINAGA; et al. 2012).

Os métodos empíricos baseiam-se na distribuição espacial das cicatrizes recentes que podem servir de indicativos para eventos futuros. A partir da indicação de áreas com maior densidade de ocorrência, pode-se induzir setores com potencial de instabilização (FERNANDES et al., op. cit.). Nesses modelos utilizam-se dados temáticos regionais tais como pluviosidade, geomorfologia, geologia, solos e declividade para se estimar a distribuição espacial de áreas susceptíveis a movimentos de massa.

Os métodos probabilísticos adotam análises com bases estatísticas, o que diminui a subjetividade da abordagem. Porém, é importante destacar que esse tipo de análise demanda a disponibilidade de extensos bancos de dados sobre os processos estudados, o que é raro na realidade brasileira (FERNANDES et al., op. cit.).

Os métodos determinísticos são análises que utilizam modelos matemáticos em bases físicas para induzir a instabilidade das vertentes. Esses métodos de abordagem requerem grandes quantidades de dados obtidos em análises laboratoriais e em ensaios de campo, sendo assim, mais apropriados para fornecerem dados quantitativos dos perigos, sendo muito úteis para a implementação de projetos de engenharia. Infelizmente, seu elevado custo inviabiliza a sua adoção em grandes extensões espaciais (TOMINAGA et al., 2012).

Os mapas de risco se referem à estimativa da extensão dos prováveis danos decorrentes de um desastre natural, sendo esses danos estimados na forma de perdas de vidas humanas, ferimentos ou prejuízos socioeconômicos. Esse tipo de mapeamento geralmente é adotado apenas para extensões espaciais limitadas, tendo em vista a complexidade inerente aos cálculos de perigos e respectivos danos (TOMINAGA et al., op.cit.). 
Existem algumas categorias de mapeamentos de risco, tais como zoneamento de risco, que envolve dimensões espaciais extensas, e cadastro de risco, que é utilizado para a identificação de unidades de construção civil com elevada suscetibilidade à ocorrência de um evento danoso. Nesse último caso, devem ser tomadas medidas preventivas, como desocupações, para aquelas construções que se encontram em situação de risco.

\section{SUSCETIBILIDADE À OCORRÊNCIA DE MOVIMENTOS DE MASSA NO MACIÇO DE BATURITÉ}

Tendo em vista que se tratam de fenômenos morfodinâmicos importantes, as informações relacionadas com movimentos de massa devem ser consideradas nas estratégias de planejamento ambiental na área do maciço. Dessa forma, faz-se necessária a identificação de áreas com maior ou menor suscetibilidade de ocorrência desses eventos.

Um dos maiores intuitos desse trabalho é a possibilidade de se estabelecer, a partir da interpretação dos processos atuais e pretéritos, tendências futuras. Nessa perspectiva, o mapa de suscetibilidade à ocorrência de movimentos de massa pode ser utilizado como uma ferramenta de políticas públicas em escala regional. É importante destacar que esse mapa tem um caráter indicativo, sendo apresentado em escala regional.

De maneira geral, o mapa de suscetibilidade corresponde à probabilidade espacial e temporal de ocorrer um movimento de massa e foi elaborado a partir da adoção de métodos empíricos qualitativos, onde foram julgados os critérios considerados como relevantes a partir da utilização de sistemas de informação geográfica, atribuindo-se índices aos fatores que afetam a instabilidade das encostas.

O referido mapa foi elaborado a partir de técnicas de álgebra de mapas, com o auxílio do software ArcGis 9.3.1., através de sua extensão spatial analyst tools, que permite a interpolação de diversos dados cartográficos relevantes para a temática. Na elaboração desse mapa, foi adotada a técnica de média ponderada que permite a estimativa da importância relativa de cada critério envolvido no processo.

No algoritmo de média ponderada são considerados dois fatores, o peso e as notas. O peso representa o percentual atribuído de acordo com a influência direta da variável mapeada sobre o desencadeamento de movimentos de massa, enquanto que a nota é o valor de número inteiro, variando de 0 (mínimo) a 5 (máximo), definido de acordo com o grau de importância que cada classe exerce sobre os eventos morfodinâmicos em questão. Dessa maneira, adota-se a seguinte fórmula matemática:

$\mathrm{MP}=\left(\mathrm{P}_{1} \times \mathrm{N}_{1}\right)+\left(\mathrm{P}_{2} \times \mathrm{N}_{2}\right)+\left(\mathrm{P}_{3} \times \mathrm{N}_{3}\right) \ldots+\left(\mathrm{P}_{\mathrm{n}} \times \mathrm{N}_{\mathrm{n}}\right)$

Onde:

MP: Média Ponderada;

$\mathrm{P}_{\mathrm{n}}$ : Peso da camada em \%;

$\mathrm{N}_{\mathrm{n}}$ : Nota de cada classe da camada.

Conforme foi possível compreender ao longo do trabalho, os movimentos de massa são eventos morfodinâmicos que estão associados com uma grande complexidade de fatores naturais e antrópicos. Dessa forma, para que sejam estabelecidos critérios relacionados com a suscetibilidade à ocorrência de movimentos massa no maciço de Baturité, devem ser analisadas as variáveis que estão diretamente relacionadas com esses eventos e qual a sua posição hierárquica dentro desse critério diante das demais variáveis. Além das variáveis, devem-se estabelecer também critérios hierárquicos para as classes das variáveis. 
Face ao exposto, foram consideradas seis variáveis, com relação à suscetibilidade de movimentos de massa no maciço de Baturité, que são elas: Declividade, Pluviosidade, Vegetação/Uso e Ocupação, Geomorfologia, Pedologia e Geologia. É importante destacar que todas essas variáveis foram individualmente mapeadas, em escalas e referências cartográficas similares, para que fosse possível a interpolação dos dados.

Matematicamente, as variáveis consideradas devem apresentar valores de peso percentual face à sua importância para o evento em análise (movimento de massa). Dessa forma, foram estabelecidas as seguintes proporções de peso: Declividade (25\% ou 0,25), Pluviosidade (25\% ou 0,25), Vegetação/Uso e Ocupação (15\% ou 0,15$)$, Geomorfologia $(15 \%$ ou 0,15$)$, Pedologia $(15 \%$ ou 0,15$)$ e Geologia ( $5 \%$ ou 0,05$)$.

Além dos pesos das variáveis, também foi estabelecida uma hierarquia de importância relacionada ao desencadeamento de movimentos de massa para cada uma das classes mapeadas nas variáveis. Tal hierarquia possui pontuação de 1 até 5 , sendo 1 o valor que apresenta menor relevância no desencadeamento de movimentos de massa, e 5 o mais importante para tal evento.

Dentre os parâmetros considerados, a declividade é um dos que apresenta maior importância no desencadeamento de movimentos de massa. Sua variação influencia diretamente na ocorrência desses eventos, na sua classificação e na capacidade energética de transporte. Dessa forma, foram estabelecidas cinco classes com intervalos de declividade que receberam diferentes notas, de acordo com a inclinação do ângulo das encostas (Quadro 1).

Quadro 1: Considerações sobre a variável "declividade" (25\%), na elaboração do mapa de suscetibilidade à ocorrência de movimentos de massa no maciço de Baturité.

\begin{tabular}{|l|c|c|c|}
\hline \multicolumn{1}{|c|}{ Classes (Declividade em graus) } & Peso & Nota & Valor final (PxN) \\
\hline $0-5$ & 0,25 & 01 & 0,25 \\
\hline $5-15$ & 0,25 & 02 & 0,50 \\
\hline $15-25$ & 0,25 & 03 & 0,75 \\
\hline $25-35$ & 0,25 & 04 & 1,00 \\
\hline $35-90$ & 0,25 & 05 & 1,25 \\
\hline
\end{tabular}

A grande maioria dos movimentos de massa do maciço de Baturité tem seu desencadeamento relacionado com significativos eventos chuvosos. Dessa forma, utilizou-se a distribuição espacial da média pluviométrica do maciço de Baturité, que foi apresentada em seis intervalos de pluviosidade média anual, que foi elaborada por Bétard (2007). De acordo com os totais pluviométricos médios, cada intervalo recebeu uma nota conforme pode ser observado no Quadro 2.

Quadro 2: Considerações sobre a variável "pluviosidade" (25\%), na elaboração do mapa de suscetibilidade à ocorrência de movimentos de massa no maciço de Baturité.

\begin{tabular}{|l|c|c|c|}
\hline Classes (Pluviosidade média anual em mm) & Peso & Nota & $\begin{array}{c}\text { Valor final } \\
(\text { PxN })\end{array}$ \\
\hline $500-700$ & 0,25 & 01 & 0,25 \\
\hline $700-900$ & 0,25 & 01 & 0,25 \\
\hline $900-1100$ & 0,25 & 02 & 0,50 \\
\hline $1100-1300$ & 0,25 & 03 & 0,75 \\
\hline $1300-1500$ & 0,25 & 04 & 1,00 \\
\hline$>1500$ & 0,25 & 05 & 1,25 \\
\hline
\end{tabular}


A ação antrópica pode apresentar relações diretas com o desencadeamento de movimentos de massa e sua principal contribuição está associada com a retirada da cobertura vegetal e com alterações geométricas nas encostas através de cortes.

A vegetação se apresenta como um agente protetor para os solos contra os efeitos erosivos lineares e areolares. $\mathrm{Na}$ área de estudo existem quatro representantes fitogeográficos (caatinga, mata de tabuleiro, mata seca e mata úmida) que exercem diferentes formas de proteção para o solo, de acordo com o adensamento e o aspecto fisionômico de seus indivíduos. Dessa forma, também foi utilizado o mapa de vegetação/uso e ocupação do maciço de Baturité como um importante critério relacionado com movimentos de massa. As áreas que apresentam vegetação em um bom estado de conservação receberam pesos relacionados com o adensamento florestal de sua unidade fitogeográfica (Quadro 3).

Com relação às formas de uso e ocupação, optou-se por não detalhar as formas de cultivo, em função da escala, considerando-se assim, apenas as formas de uso mais relacionadas com os movimentos de massa. Dessa forma, foram mapeadas três classes de uso (áreas desmatadas/cultivos, estradas e áreas urbanas) que receberam a mesma nota, conforme pode ser observado no Quadro 3.

As formas de relevo também se apresentam como um importante critério no mapa de suscetibilidade, tendo em vista que os movimentos de massa variam de acordo com a feição geomorfológica de ocorrência. Dessa forma, é fundamental espacializar as unidades de relevo, pois cada uma delas pode apresentar movimentos de massa bastante específicos. Tendo em vista a identificação em campo dos movimentos de massa nas diferentes unidades geomorfológicas, foram estabelecidos pesos distintos para cada unidade de relevo mapeada, conforme pode ser observado no Quadro 4.

Quadro 3: Considerações sobre a variável "vegetação/uso e ocupação" (15\%), na elaboração do mapa de suscetibilidade à ocorrência de movimentos de massa no maciço de Baturité.

\begin{tabular}{|l|c|c|c|}
\hline $\begin{array}{l}\text { Classes } \\
\text { (Unidades fitogeográficas conservadas e formas de uso e } \\
\text { ocupação) }\end{array}$ & Peso & Nota & Valor final (PxN) \\
\hline Mata Úmida & 0,15 & 02 & 0,30 \\
\hline Mata Seca & 0,15 & 03 & 0,45 \\
\hline Caatinga & 0,15 & 04 & 0,60 \\
\hline Áreas Desmatadas/Cultivo & 0,15 & 05 & 0,75 \\
\hline Estradas & 0,15 & 05 & 0,75 \\
\hline Áreas Urbanas & 0,15 & 05 & 0,75 \\
\hline
\end{tabular}

Quadro 4: Considerações sobre a variável "geomorfologia" (15\%), na elaboração do mapa de suscetibilidade à ocorrência de movimentos de massa no maciço de Baturité.

\begin{tabular}{|l|c|c|c|}
\hline Classes (Formas de relevo) & Peso & Nota & Valor final (PxN) \\
\hline Cristas & 0,15 & 05 & 0,75 \\
\hline Colinas & 0,15 & 03 & 0,45 \\
\hline Alvéolos & 0,15 & 01 & 0,15 \\
\hline Vertente dissecada úmida & 0,15 & 05 & 0,75 \\
\hline Domo Rochoso & 0,15 & 05 & 0,75 \\
\hline Vertente dissecada seca & 0,15 & 05 & 0,75 \\
\hline Inselberg & 0,15 & 04 & 0,60 \\
\hline Carste & 0,15 & 03 & 0,45 \\
\hline Piemont úmido & 0,15 & 01 & 0,15 \\
\hline Piemont semi-árido & 0,15 & 01 & 0,15 \\
\hline Planície fluvial & 0,15 & 01 & 0,15 \\
\hline Tabuleiros clásticos & 0,15 & 01 & 0,15 \\
\hline Tabuleiros arenosos & 0,15 & 01 & 0,15 \\
\hline
\end{tabular}


Pode-se observar que as unidades geomorfológicas que apresentam formas mais aguçadas, tais como cristas e vertentes dissecadas, receberem nota maior, enquanto que formas mais conservadas receberam notas menores.

Vale destacar que a identificação das unidades geomorfológicas foi feita tendo como base o mapa geomorfológico elaborado por Bétard (2007) e, posteriormente, detalhado por Bastos (2012).

O maciço de Baturité e sua área de entorno apresentam variações pedológicas em função da variação espacial dos aspectos naturais. Com relação às notas estabelecidas aos tipos de solo na área com relação aos movimentos de massa, foram utilizados critérios que levaram em consideração não apenas o solo e suas propriedades morfológicas, mas a situação da área em que ele se encontra.

Dessa forma, os argissolos, que possuem importantes planos de descontinuidade textural entre os horizontes A e B, receberam nota 3, pois encontram-se recobertos por florestas em ambientes dissecados. Por suas propriedades físicas, em função de serem altamente suscetíveis à erosão, os luvissolos e os neossolos litólicos receberam nota 5. Os demais solos são também suscetíveis à erosão, porém se encontram em topografias planas e, por essa razão, receberam nota 3 (Quadro 5).

Quadro 5: Considerações sobre a variável "pedologia" (15\%), na elaboração do mapa de suscetibilidade à ocorrência de movimentos de massa no maciço de Baturité.

\begin{tabular}{|l|c|c|c|}
\hline Classes (Tipos de solos) & Peso & Nota & Valor final (PxN) \\
\hline Argissolos Distróficos & 0,15 & 03 & 0,45 \\
\hline Argissolos Eutróficos & 0,15 & 03 & 0,45 \\
\hline Luvissolos & 0,15 & 05 & 0,75 \\
\hline Neossolos Flúvicos & 0,15 & 03 & 0,45 \\
\hline Neossolos Litólicos & 0,15 & 05 & 0,75 \\
\hline Neossolos Quartzarênicos & 0,15 & 03 & 0,45 \\
\hline Planossolos & 0,15 & 03 & 0,45 \\
\hline
\end{tabular}

O estabelecimento de pesos para as diferentes estruturas geológicas da área de estudo se destaca como uma tarefa bastante complexa e difícil. Isso se deve ao fato de que diferentes tipos de rochas apresentam propriedades geomorfológicas distintas, sobretudo com relação à sua resistência contra os efeitos do intemperismo e erosão. No que tange à ocorrência de movimentos de massa, a forma como a estrutura se encontra (grau de intemperismo, presença de fraturas, etc.) é mais importante que a simples identificação da litologia. Como não se dispunha de um mapeamento facilógico das litologias, sobretudo quanto ao seu grau de intemperismo ou com relação à presença de fraturas ou diaclases, optou-se por adotar o peso 0,5 para essa variável.

As estruturas sedimentares recentes (sedimentos aluviais e da Formação Barreiras) se apresentam inconsolidadas, porém, em setores topográficos planos, daí o fato de terem recebido nota 3. As rochas intrusivas, devido à sua elevada resistência, receberam nota 2. Os quartzitos e metacalcários receberam nota 3 e as rochas metamórficas mais fraturadas e alteradas, de forma geral, receberam nota 4, conforme pode ser observado no Quadro 6.

É importante destacar que foram feitos alguns ensaios ou testes com pesos diferentes para as classes anteriormente apresentadas, porém, os resultados finais apresentavam uma suscetibilidade à ocorrência de movimentos de massa inconsistente com a realidade local. Assim, os referidos pesos considerados foram os que geraram melhores resultados com relação à realidade e isso pode ser constatado quando se verifica que a maior parte das cicatrizes de movimentos de massa se encontra nas áreas de suscetibilidade alta (Figura 3). 
Quadro 6: Considerações sobre a variável "geologia" $(0,5 \%)$, na elaboração do mapa de suscetibilidade à ocorrência de movimentos de massa no maciço de Baturité.

\begin{tabular}{|l|c|c|c|}
\hline Classes (Estrutura geológica) & Peso & Nota & Valor final (PxN) \\
\hline Aluviões & 0,05 & 3 & 0,15 \\
\hline Formação Barreiras & 0,05 & 3 & 0,15 \\
\hline Dioritos e Gabros & 0,05 & 2 & 0,10 \\
\hline Granitóides Diversos & 0,05 & 2 & 0,10 \\
\hline Quartzitos & 0,05 & 3 & 0,15 \\
\hline Metacalcários & 0,05 & 3 & 0,15 \\
\hline Ortognaisses & 0,05 & 4 & 0,20 \\
\hline Migmatitos & 0,05 & 4 & 0,20 \\
\hline Paragnaisses & 0,05 & 4 & 0,20 \\
\hline
\end{tabular}

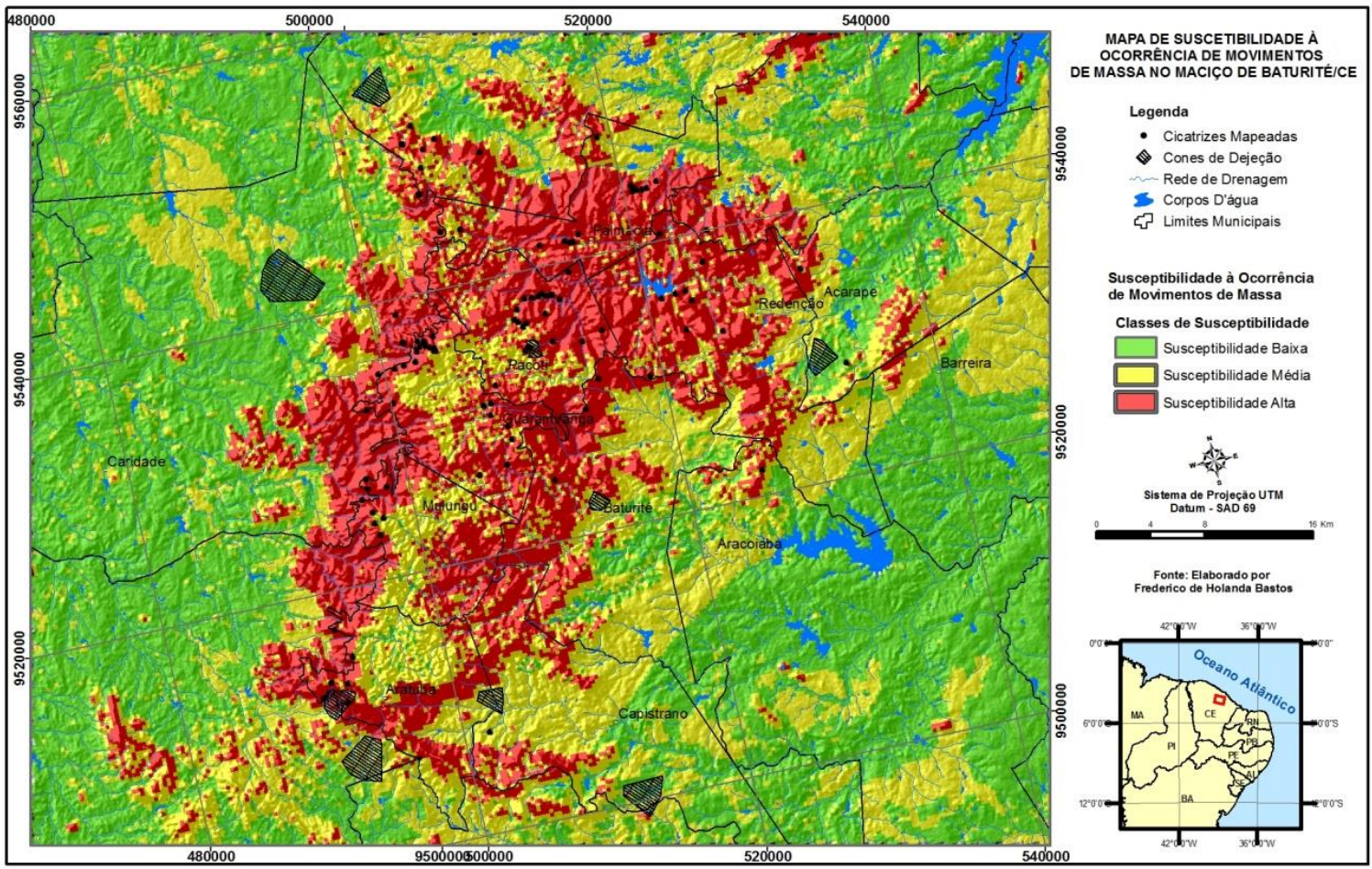

Figura 3: Suscetibilidade à ocorrência de movimentos de massa no maciço de Baturité/CE.

\section{RESULTADOS E DISCUSSÕES}

A partir da adoção dos critérios anteriormente mencionados, foi possível confeccionar um mapa de suscetibilidade à ocorrência de movimentos de massa no maciço de Baturité, que apresentou três graus de suscetibilidade (alta, média e baixa), com resultados bastante satisfatórios com relação à distribuição espacial das áreas.

\section{Suscetibilidade alta}

Foram identificadas três áreas com alta suscetibilidade à ocorrência de movimentos de massa no maciço de Baturité e seu entorno: a vertente dissecada seca, setores orientais elevados da vertente dissecada úmida e setores setentrionais elevados da vertente dissecada úmida.

A vertente dissecada seca corresponde aos setores de quartzitos dobrados na Unidade Independência que abrangem as áreas ocidentais e meridionais do maciço. Essas áreas incorporam parte dos municípios de Guaramiranga, Mulungu, Aratuba, Caridade e Canindé. Os movimentos de massa suscetíveis de ocorrerem nessas áreas são basicamente deslizamentos translacionais rasos e 
quedas de blocos. Como existem fortes declividades $\left(>30^{\circ}\right)$, a capacidade energética é bastante considerável, justificando a possibilidade de movimentos muito rápidos.

Os materiais envolvidos com os movimentos de massa nesses setores são pequenos mantos de alteração, associados com neossolos litólicos, e blocos rochosos que se desprendem das cornijas de quartzito. A maior parte dos riscos ocorre nas estradas. Algumas rodovias como a CE-253 e a CE257 apresentam trechos com elevado risco de soterramento de parte da pista ou, até mesmo, o colapso de parte destas.

Os setores orientais elevados da vertente dissecada úmida incorporam parte dos municípios de Pacoti, Guaramiranga, Mulungu, Baturité e Redenção e abrangem os altos cursos das sub-bacias hidrográficas dos rios Choró e Pacoti, se destacando como os ambientes mais úmidos de toda a região. Nesse setor podem ocorrer deslizamentos rotacionais e translacionais, fluxos de lama e quedas de blocos. Os declives possuem valores sensivelmente menores do que nos setores ocidentais/meridionais, porém, constata-se também uma elevada capacidade energética.

Os movimentos de massa dessas áreas transportam geralmente profundos mantos de intemperismo, associados com argissolos, e blocos de variadas dimensões. Em alguns locais, como na comunidade do Rolador, em Pacoti, encontram-se antigas cicatrizes de blocos de dimensões métricas pesando toneladas, indicando a elevada energia dos movimentos. Os riscos nessa área também estão associados com rodovias e algumas áreas residenciais isoladas. A ocorrência dos movimentos está predominantemente relacionada com a saturação dos solos durante as estações chuvosas, principalmente nos meses de março e abril.

Os setores setentrionais elevados da vertente dissecada úmida apresentam encostas íngremes, formadas por migmatitos fortemente fraturados, abrangendo basicamente parte dos municípios de Palmácia e Maranguape. Nesse caso, os movimentos que podem ocorrer são quedas de blocos e deslizamentos translacionais rasos. O material transportado pode ser composto por pequenos mantos de intemperismo e blocos soltos de migmatito, que conseguem se transportar rapidamente em função da elevada capacidade energética relacionada à forte declividade. Assim como as demais áreas, os riscos estão associados com rodovias. Nesse caso, merece destaque a CE-065 que apresenta trechos com elevado risco de quedas de blocos e deslizamentos.

De maneira geral, em toda a área do maciço de Baturité, a maioria das cicatrizes de movimentos de massa identificadas se encontra em declividades situadas entre $15^{\circ}$ e $35^{\circ}$. Em todas as áreas de alta suscetibilidade pode haver desencadeamento de movimentos de massa associado com atividades agrícolas, sobretudo com culturas de sequeiro (milho e feijão).

Uma importante constatação que pôde ser feita com o advento do mapa de suscetibilidade à ocorrência de movimentos de massa foi que, nenhuma sede municipal de encontra em área de alta suscetibilidade e isso se justifica pelo fato delas se localizarem, predominantemente, em fundos de vales. Cabe aqui destacar, que o presente mapeamento foi realizado em escala regional, podendo ocorrer alguns setores residenciais em sedes urbanas configurando áreas de risco pontuais.

De acordo com a Figura 4, pode-se constatar que a grande maioria das áreas de alta suscetibilidade à ocorrência de movimentos de massa encontra-se fora da APA da Serra de Baturité, ou seja, está abaixo da cota $600 \mathrm{~m}$. Essa é uma informação muito importante, tendo em vista que, as áreas morfodinamicamente mais instáveis não estão contempladas com nenhuma categoria de unidade de conservação.

\section{Suscetibilidade média}

As áreas com média suscetibilidade à ocorrência de movimentos de massa se localizam no platô, acima da cota $600 \mathrm{~m}$, nos setores mais baixos das vertentes dissecadas seca e úmida e nos inselbergs dispersos ao longo dos sertões. Nessas áreas foram identificados alguns movimentos de massa de pequena magnitude, geralmente associados com deslizamentos translacionais rasos em margens de rodovias nas áreas do platô. 


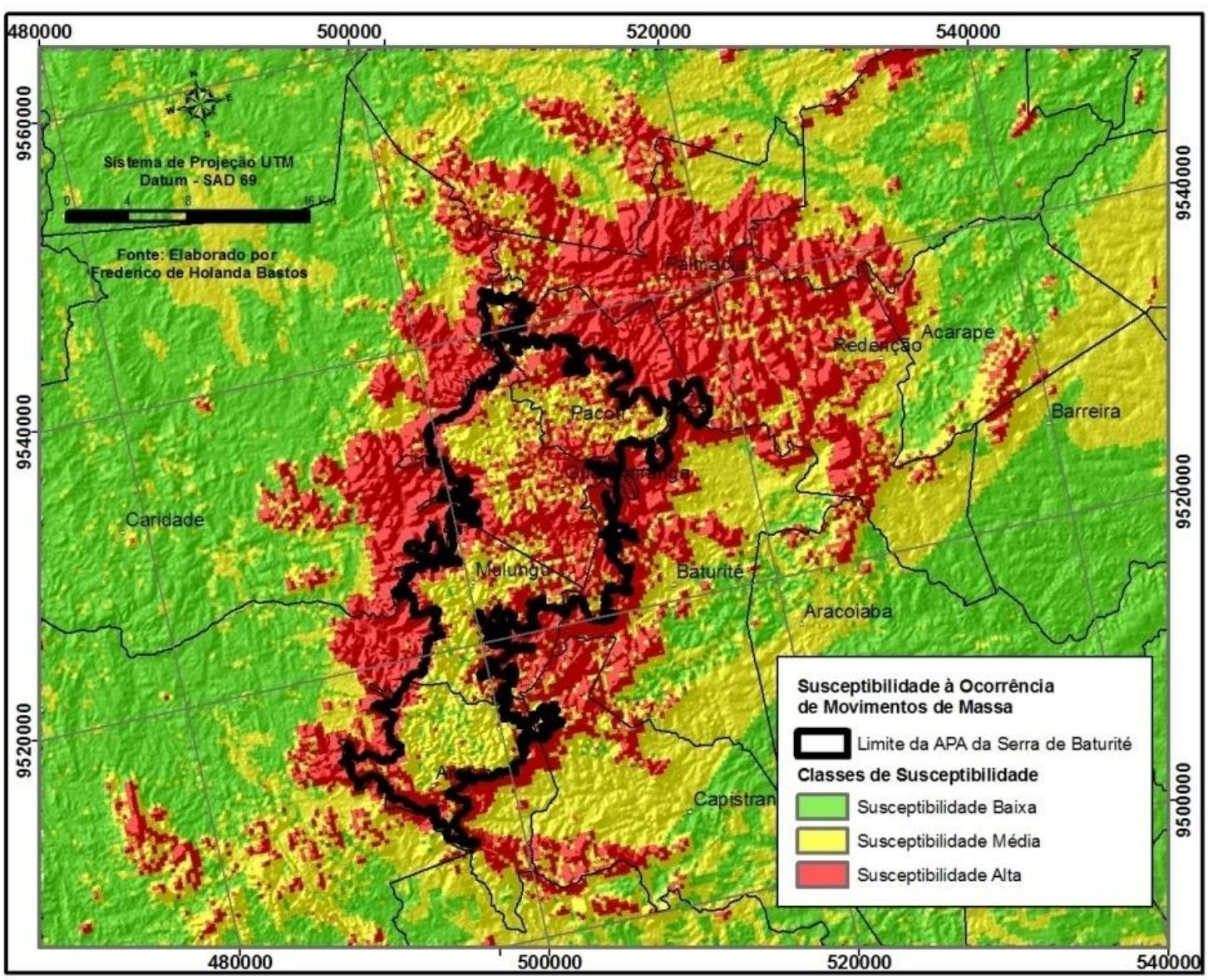

Figura 4: Limite da APA da Serra de Baturité associado com o Mapa de Suscetibilidade à Ocorrência de Movimentos de Massa.

No platô predominam relevos convexos (colinas ou meias-laranjas), compostos por gnaisses e micaxistos, intercalados com planícies alveolares, formadas por depósitos colúvio-aluviais. Tratamse de áreas com morfodinâmica tendendo à estabilidade e isso se deve, sobretudo, ao bom estado de conservação em que a mata úmida se encontra e às condições topográficas mais suaves, com declives predominantemente inferiores a $15^{\circ}$.

Outro fator positivo para a estabilidade morfodinâmica dos relevos do platô está associado à unidade de conservação (APA da Serra de Baturité) que abrange toda essa área e dificulta a realização de práticas predatórias. Uma das formas de cultivo mais desenvolvidas nessa área é a cafeicultura, que é desenvolvida em consórcio com espécies arbóreas, diminuindo os desmatamentos.

Os setores rebaixados das vertentes dissecadas seca e úmida constituem, de forma geral, as bases do maciço de Baturité ou o início do piemont, podendo, em alguns casos apresentar cones de acumulação de detritos, depositados em eventos morfodinâmicos pretéritos. Esses setores estão localizados ao redor de todo o maciço.

Algumas áreas de deposição de detritos podem sofrer processos de remobilização do material a partir de atividades antrópicas capazes de instabilizar suas encostas. Nesses casos, os detritos podem ser novamente transportados por outros processos morfodinâmicos como fluxos ou creep, dependendo dos agentes desencadeadores.

Com relação aos inselbergs, não foram identificadas cicatrizes de movimentos de massa, porém, seus flancos podem apresentar declives superiores a $25^{\circ}$, induzindo o transporte acelerado de qualquer material que se desprenda da rocha matriz, configurando, nesse caso, queda de blocos. 


\section{Suscetibilidade baixa}

Os setores que apresentam suscetibilidade baixa à ocorrência de movimentos de massa são as superfícies sertanejas e as áreas de deposição Cenozóica, que podem se encontrar em áreas elevadas do maciço ou em superfícies rebaixadas circunvizinhas. Os declives inferiores a $5^{\circ}$ se destacam como o principal fator para a sua estabilidade morfodinâmica.

Os setores elevados do maciço com baixa suscetibilidade constituem as planícies alveolares, que são unidades geomorfológicas bastante utilizadas para o cultivo de cana-de-açúcar, banana e hortaliças. Essas áreas se situam predominantemente entre os municípios de Mulungu e Aratuba.

Os setores circunvizinhos com baixa suscetibilidade abrangem as superfícies sertanejas e os tabuleiros. As áreas sertanejas constituem superfícies de erosão formadas por rochas metamórficas e apresentam topografias suavemente onduladas, podendo ultrapassar levemente $5^{\circ}$ de declividade. Essas áreas constituem o domínio das caatingas e têm como principal atividade a pecuária e a agricultura temporária de subsistência

Os tabuleiros constituem superfícies de acumulação de sedimentos da Formação Barreiras, de granulações variadas, recobertos por mata de tabuleiro e com topografias planas, configurando os setores mais estáveis de toda a área de estudo, sob o ponto de vista morfodinâmico.

\section{CONSIDERAÇÕES FINAIS}

O presente trabalho apresentou uma proposta metodológica de mapeamento de suscetibilidade à ocorrência de movimentos de massa em um maciço úmido do Nordeste brasileiro, porém, é fundamental que sejam estabelecidos critérios no intuito de se uniformizar os mapeamentos dessa natureza nas demais regiões do país. Essa afirmação se deve ao fato de que, atualmente, é muito difícil se fazer estudos comparativos entre mapeamentos dessa natureza em diferentes regiões brasileiras e isso se deve à enorme subjetividade metodológica adotada em cada área analisada. Mesmo com as subjetividades inerentes aos mapeamentos dessa natureza, espera-se que a presente proposta metodológica possa ser aplicada em outros ambientes serranos úmidos do Nordeste brasileiro.

\section{AGRADECIMENTOS}

Os autores agradecem o auxílio financeiro fornecido pela Fundação Cearense de Apoio ao Desenvolvimento Científico e Tecnológico (FUNCAP) que foi de fundamental importância para o desenvolvimento da pesquisa.

\section{REFERÊNCIAS}

AB'SÁBER, A. N. Um conceito de geomorfologia a serviço das pesquisas sobre o Quaternário. Geomorfologia, N¹8, 1-18. IG - USP. São Paulo, 1969.

AB'SÁBER, A. N. O Domínio Morfoclimático Semi-Árido das Caatingas Brasileiras. Geomorfologia, No 43, 1-39. IG - USP. São Paulo, 1974.

ALMEIDA F. F. M., BRITO NEVES B. B., CARNEIRO C. D. R.. The origin and evolution of the South American platform. Earth Sci. Rev., 50, pp. 77-111, 2000.

ARTHAUD, M. H., CABY, R., FUCK, R. A., DANTAS, E. L., PARENTE, C. V., 2008. Geology of the northern Borborema Province, NE Brazil and its correlation with Nigeria, NW Africa. In: PANKHURST, R. J., TROUW, R. A. J., BRITO NEVES, B. B., DE WIT, M. J. (eds), West Gondwana Pre-Cenozoic correlations across the South Atlantic region. Geological society, London, Special Publications, 294, 49-67, 2008. 
BASTOS, F. H. Movimentos de massa no maciço de Baturité (CE) e contribuições para estratégias de planejamento ambiental. Universidade Federal do Ceará. Tese de Doutorado em Geografia. 257pp. Fortaleza, 2012.

BELTRAMI, C. V.; ALVES, L. E. M.; FEIJÓ, F. J. Bacia do Ceará. Rio de Janeiro. Boletim de Geociências da PETROBRÁS, 8 (1):117-125, 1994.

BÉTARD, F. Montagnes humides au coeur du nordeste brésilien semi-aride: Le cas du massif de Baturité (Ceará). Universidade de Paris IV - Sorbonne. Tese de Doutorado. 443pp. Paris, 2007.

BETARD, F., PEULVAST, J. P. Evolução morfoestrutural e morfopedológica do maciço de Baturité e de seu piemont: do Cretáceo ao Presente. In BASTOS, F. H. (org.): Serra de Baturité: Uma Visão Integrada das Questões Ambientais: 35-60. Expressão Gráfica e Editora, Fortaleza.. Fortaleza, 2011.

BIGARELLA, J. J., BECKER, R. D., PASSOS, E. Estrutura e Origem das Paisagens Tropicais e Subtropicais: 877-1436. Ed. UFSC. V.3. Florianópolis, 2003.

BRITO NEVES, B. B. de. Elementos da geologia pré-cambriana do Nordeste oriental. In: SBG, Congresso Brasileiro de Geologia, 27. Anais, 2: 105-132. Aracaju, 1973.

CASTRO, C. M., PEIXOTO, M. N. O., RIO, G. A. P. Riscos ambientais e geografia: conceituações, abordagens e escalas. Anuário do Instituto de Geociências. Vol. 28 - 2. p. 11 - 30. Rio de Janeiro, 2005.

CERRI, L. E. S., AMARAL, C. P. Riscos Geológicos (301 - 310). In: OLIVEIRA, A. M. dos S.; BRITO, S. N. A. de. (Org). Geologia de Engenharia. ABGECNPq- FAPESP. São Paulo, 1998.

CLAUDINO SALES, V., PEULVAST, J-P. Evolução morfoestrutural do relevo da margem continental do Estado do Ceará, Nordeste do Brasil. Caminhos de Geografia, Vol 7, No 2, (1-21). Uberlândia, 2007.

CPRM. Atlas Digital de Geologia e Recursos Minerais do Ceará. Mapa na escala 1:500.000. Companhia de Pesquisa de Recursos Minerais - CPRM. Serviço Geológico do Brasil. Ministério das Minas e Energia. Fortaleza, 2003.

DIKAU, R., BRUNSDEN, D., SCHROTT, L., IBSEN, M. (Eds). Landslide recognition: identification, movement and causes. J. Wiley and Sons. 251pp. Chichester, 1996.

DIKAU, R. Mass Movement. In: GOUDIE, A (Hrsg.): Encyclopedia of Geomorphology: 644 - 652 , 2004.

FERNANDES, G. A. Fitogeografia brasileira. Multigraf. 339pp - Fortaleza, 1998.

FERNANDES, G. A., VICENTE DA SILVA, E., PEREIRA, R. C. M. Fitogeografia do Maciço de Baturité: Uma Visão Sistêmica e Ecológica. In: BASTOS, F. H. (org) Serra de Baturité: Uma visão integrada das questões ambientais: 84-99. Expressão gráfica e editora. Fortaleza, 2011.

FERNANDES, N. F., AMARAL, C. P. Movimentos de Massa: Uma abordagem geológicogeomorfológica. In: GUERRA, A. J. T., CUNHA, S. B. (org). Geomorfologia e Meio Ambiente: 123 - 194. $3^{\mathrm{a}}$ edição. Editora Bertrand Brasil. Rio de Janeiro, 2000.

FERNANDES, N. F., GUIMARÃES, R. F., GOMES, R. A. T., VIEIRA, B. C., MONTGOMERY, D. R., GREENBERG, H. Condicionantes Geomorfológicos dos Deslizamentos das Encostas: Avaliação de Metodologias e Aplicações de Modelos de Previsão de Áreas Susceptíveis. Revista Brasileira de Geomorfologia. V.2, Nº 1, 51-71, 2001.

GUIDICINI, G., NIEBLE, C. M. Estabilidade de Taludes Naturais e de Escavação. 2ª.ed. Editora Edgar Blücher. 194pp. São Paulo, 1984.

MATOS, R.M.D. The Northeast brazilian rift system. Tectonics, 11, 4, pp. 766-791, 1992.

MATOS, R.M.D.. Tectonic evolution of the Equatorial South Atlantic. In: Atlantic Rifts and continental margins, Geophys. Monograph, 115, Am. Geophys. Union, pp. 331-354, 2000. 
MMA. Geossistemas e Potencialidades dos Recursos Naturais, Serra de Baturité e Áreas Sertanejas Periféricas (Ceará). Ministério do Meio Ambiente - FNMA/FCPC. 121pp. Fortaleza, FUNCEME, 1994.

MONIÉ, P., CABY, R., ARTHAUD, M., 1997. The Neoproterozoic Brasiliano orogeny in northeast Brazil: ${ }^{40} \mathrm{Ar} /{ }^{39} \mathrm{Ar}$ and petrostructural data from Ceará. Precambrian Res., 81, pp. 241-264, 1997.

PEULVAST, J. P., CLAUDINO SALES, V. Stepped surfaces and palaeolandforms in the northern Brazilian "Nordeste": constraints on models of morphotectonic evolution. Geomorphology 62, 89122. Amsterdã, 2004.

PEULVAST J.-P., BÉTARD F. Late Cenozoic and present day hillslope erosion dynamics in a passive margin context: stability or instability? Case studies in Northeast Brazil, Geografia Fisica e Dinâmica Quaternaria, 36(1), 139-149, 2013.

PICANÇO, J. Movimentos gravitacionais de massa, tragédias do verão. Scientific American, n. 94, p. $40-45,2010$.

SEMACE (Superintendência Estadual do Meio Ambiente/Ceará). Zoneamento Ambiental da APA da Serra de Baturité: diagnósticos e diretrizes. 109pp. Fortaleza, 1992.

SOUZA, M. J. N. Contribuição ao estudo das unidades Morfo-Estruturais do Estado do Ceará. Revista de Geologia, (1): 73-91, junho/1988.

SOUZA, M. J. N.; OLIVEIRA, V. P. V. Os enclaves úmidos e sub-úmidos do semi-árido do Nordeste brasileiro. Mercator, ano 5, $85-102, \mathrm{~N}^{\circ}$ 9. Fortaleza, 2006.

TOMINAGA, L. K., SANTORO, J., AMARAL, R. (Orgs.). Desastres Naturais: Conhecer para Prevenir. 2a Ed. Instituto Geológico. 196 pp. São Paulo, 2012.

UN-ISDR. International Strategy for Disaster Reduction. 2009. Terminology on Disaster Risk Reduction. Disponível em <http://www.unisdr.org>. Acesso em 26 de junho de 2012.

VARNES, D. J. Slope movement types and process, in SCHUSTER, R. L., KRIZEK, R.J. (eds). Landslides analysis and control. Transportation Research Board. National Academy of Sciences, Special Report 176, 12 - 33. 1978.

ZANELLA, M. E., SALES, M. C. L. Considerações sobre o clima e a hidrografia do maciço de Baturité. In: BASTOS, F. H. (org) Serra de Baturité: Uma visão integrada das questões ambientais: 61-76. Expressão gráfica e editora. Fortaleza, 2011.

ZEMBRUSCKI, S. G.; BARRETO, H. T.; PALMA, J. J. C.; MILLIMAN, J. D. Estudo Preliminar das províncias geomorfológicas da margem continental brasileira. Rio de Janeiro. PETROBRÁS. Projeto Remac 1: 169-191, 1975. 